\title{
IMPACT OF ANTIOXIDANTS SUPPLEMENTATION ON GROWTH, YIELD AND QUALITY TRAITS OF CANOLA (Brassica napus L.) UNDER IRRIGATION INTERVALS IN NORTH NILE DELTA OF EGYPT
}

\author{
A. EL Sabagh ${ }^{1, *}$, Kh. A. A. Abdelaal ${ }^{2}$ and C. Barutcular ${ }^{3}$ \\ ${ }^{1}$ Department of Agronomy, Faculty of Agriculture, Kafrelsheikh University, Egypt \\ ${ }^{2}$ Agricultur Botany Department, Faculty of Agriculture, Kafrelsheikh University, Egypt \\ ${ }^{3}$ Department of Field Crops, Faculty of Agriculture, Cukurova University, Turkey
}

Received - March 30, 2017; Revision - April 29, 2017; Accepted - May 10, 2017

Available Online - May 12, 2017

DOI: http://dx.doi.org/10.18006/2017.5(2).163.172

KEYWORDS
Brassica napus
Ascorbic acid
Salicylic acid
Irrigation
Quality
Yield

\begin{abstract}
In the present study, field experiments were carried out during the cropping seasons of 2012 and 2013 to examine the adverse effects of deficit irrigation on canola productivity and determining the role of ascorbic acid and salicylic acid (both of $200 \mathrm{ppm}$ ) in alleviating the adverse effects under deficit irrigation. Further, effects of these phytochemicals on canola growth, yield and quality characteristics were studied by imposing three irrigation intervals viz, $25\left(\mathrm{I}_{1}\right), 35\left(\mathrm{I}_{2}\right)$ and $45\left(\mathrm{I}_{3}\right)$ days during both the growing seasons. The results of the study showed that the growth characteristics such as chlorophyll content and relative water content were decreased under the increase in irrigation intervals. Similarly, Yield and its components including plant height, silica number/plant, number of branches, seed number/ silica, seed yield/plant, seed yield / ha as well as, seed oil content of canola plant were decreased with increasing the intervals of irrigations. Application of both of phytochemical (salicylic acid and ascorbic acid) not only reversed the negative impact of water deficit conditions but also improved the growth and yield parameters of canola plant. However, the applications of antioxidants were more effective under the second irrigation intervals $\left(\mathrm{I}_{2}\right)$ for both the cropping seasons. The maximum seed yield /ha, protein and oil yield was achieved by the applications of both antioxidants combined with irrigation every 35 days. From results of this study, it can be conclude that application of antioxidants could mitigate the harmful effects of deficit irrigation of canola. Accordingly, antioxidants supplementation could enhance the growth, yield and quality traits of canola under the increase of irrigation intervals in North Nile Delta.
\end{abstract}

* Corresponding author

E-mail: aymanelsabagh@gmail.com (A. EL Sabagh)

Peer review under responsibility of Journal of Experimental Biology and Agricultural Sciences.

Production and Hosting by Horizon Publisher India [HPI] (http://www.horizonpublisherindia.in/).

All rights reserved.
All the article published by Journal of Experimental Biology and Agricultural Sciences is licensed under a Creative Commons Attribution-NonCommercial 4.0 International License Based on a work at www.jebas.org.

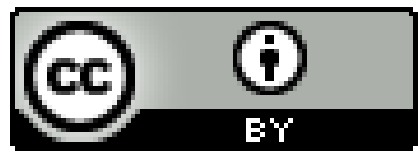




\section{Introduction}

In Egypt, there is a great challenge to fulfill the demand of edible oils for the population, where, the approximate amount of edible oil imports (95 to 97\%) form various countries (Anonymous 2013).Therefore, efforts to be needed for increasing the local production from edible oil and reducing the gap between production and consumption. Canola (Brassica napus L.) ranked 3rd in oil yielding crops and is the most important source of plant oil in the world. Seeds of canola contain $40-42 \%$ oil and $25 \%$ protein. In case of oil contents, its oil contains $61 \%$ oleic acid, $8.8 \%$ linoleic acid, and quality wise it's superior to the other oil seeds (Reyes, 2007). Moreover, it has very low saturated fatty acids, which raising daily demand of canola oil in diet aware consumers (Rastegar, 2004). Further, canola seeds are distinguished by low erucic acid and glucosinolate. Safe limits for these compounds have been described as less than $2 \%$ of erucic acid in oil and less than $30 \mu \mathrm{mol} \mathrm{g-1}$ of glucosinolate in oil free meals. Since, high content of erucic acid and glucosinolate in rapeseed are considered toxic to humans and animals. Moreover, the residue left after oil extraction is rich in proteins and can be used for animal feeding (Dawood \& Sadak, 2014).

In case of canola cultivation, water deficiency has deleterious effects on both vegetative and reproductive growth stages while in case of rapeseed; it has higher determining effect on the reproductive growth phase (Ghobadi et al., 2006). Rape crops are highly susceptible to water stress during pre-flowering (10-12 days before anthesis) and flowering stages and exposures to drought during these stages may cause fewer flowers set, silica and seed sterility (Lizana et al., 2006). Further, drought stress at flowering stage adversely affects pod formation and seed size, which ultimately results in less economic yield (Johnston et al., 2002).Generally, mismanagement of the agronomic practices factors influence the growth, yield and quality of the canola (EL Sabagh et al., 2015a; EL Sabagh et al., 2016 a; EL Sabagh et al., 2016 b).

Enhancing of tolerance to stress conditions of plant is a viable approach to resolve this problem induced by climate change. Some phytochemicals like salicylic acid or ascorbic acid plays significant role in enhancing drought tolerance in plants (Hamada, 2000; Kazemi, 2014). Effect of Salicylic acid (SA) on plant growth and physical progress of crop was reported by various studies (Amin et al., 2008; Kowalczyk \& Zielony 2008). According to Shakirova et al. (2003) and Hayat (2010) salicylic acid actively involved in the various biochemical and physiologic mechanism of plant, which help them to mitigate the adverse effect of the water stress conditions. Further, salicylic acid also plays an important role in regulation of various plant physiological processes such as photosynthesis or non-enzymatic antioxidant (ElKhallal et al., 2009; Salarizdah et al., 2012).

Further, role of ascorbic acid in regulation of plant growth, cell division, cell wall expansion and other developmental processes have been well reported by Pignocchi \& Foyer (2003). Further,
Ascorbate worked in coordination with glutathione and several enzymatic antioxidants to counteract the $\left(\mathrm{O}_{2}\right)$ radicals that are produced by the Mehler reaction and photorespiration (Noctor \& Foyer, 1998).This removal of free radical, helps ascorbate in increasing stress tolerance and reduce oxidative stress (Shalata \& Neumann, 2001). According to Rosales et al. (2006) ascorbic acid improve the cell division and causes improvement in fresh and dry weight of leaf on plants and reducing the injury from oxygen radicals under drought stress conditions.

Presently, Egypt is facing problem associated with the shortage of local production of oil producing crops as compared to their consumption. Further availability of water is also a major problem in crop production under Egyptian conditions. Therefore, adopting suitable agricultural practices might affect the productivity of canola. Therefore, current study was undertaken to examine the adverse effects of irrigation intervals on canola and role of ascorbic acid and salicylic acid in mitigating the adverse effects of deficit irrigation.

\section{Materials and Methods}

\subsection{Experimental setup and cultivation conditions}

This study was conducted at the experimental station of Kafrelsheikh University, Egypt during the two consecutive growing seasons of 2012-2013 and 2013-2014. Climatic data were collected from Sakha agro-meteorological station, as described in (Table 1). Soil samples were obtained from the 0 to $30 \mathrm{~cm}$ depth and the amount of $\mathrm{N}$ from the collected soil samples were measured by Kjeldahl method (Bremner, 1960). The characteristic of the collected soil sample was clay and an average bulk density of $1.22 \mathrm{~g} \mathrm{~cm}^{-3}$ in upper $30 \mathrm{~cm}$ depth. Further, This layer also contained $1.37 \%$ total organic matter, $0.15 \%$ total nitrogen $(\mathrm{N}), 35$ $\mathrm{mg} \mathrm{kg}^{-1}$ available phosphorus (P) and $255.3 \mathrm{mg} \mathrm{kg}^{-1}$ exchangeable potassium $(\mathrm{K}), \quad 1.25 \mathrm{EC},\left(\mathrm{dS} \mathrm{m}^{-1}, 1: 5\right)$ and $8.1 \mathrm{pH}(1: 2.5)$ as average in both seasons were described according to Black (1965) .

\subsection{Experimental design, Plant materials and treatments}

The experiment was laid out as a split plot arrangement in a randomized complete block design with four replications. Each plot was $10.5 \mathrm{~m}^{2}$ and has 6 rows $(3.5 \mathrm{~m}$ long and $50 \mathrm{~cm}$. apart) with $20 \mathrm{~cm}$ distance between hills. Seeds of canola cultivar namely (Serw-4: Egyptian cultivar) were obtained from the Ministry of Agriculture Oil Crop Research Center Giza, Egypt. The irrigation scheduling were $\left(25\left(\mathrm{I}_{1}\right), 35\left(\mathrm{I}_{2}\right)\right.$ and $45\left(\mathrm{I}_{3}\right)$ which was arranged in the main plots, considering first irrigations.

Further, salicylic acid (SA) at the concentrate of $200 \mathrm{ppm}$ and ascorbic acid at the same level were applied in the sub-plots. Automatic atomizers were used for applying the antioxidants after adding tween 20 as a wetting agent at the level of $0.05 \%$.The plants were sprayed at two stages, the first at budding (45 DAS) and the second was at initiation of flowering stage (75 DAS). 
Table 1 Monthly relative humidity $(\mathrm{RH}, \%)$, wind speed $\left(\mathrm{kg} \mathrm{day}^{-1}\right)$, mean minimum and maximum air temperatures $\left(\mathrm{T}_{\max }\right.$ and $\mathrm{T}_{\min }$, respectively) during the two growing seasons.

\begin{tabular}{|c|c|c|c|c|c|c|c|c|}
\hline \multirow{3}{*}{$\begin{array}{l}\text { Season } \\
\text { Month }\end{array}$} & \multicolumn{4}{|c|}{2012} & \multicolumn{4}{|c|}{2013} \\
\hline & \multicolumn{2}{|c|}{ Temperature $\left({ }^{\circ} \mathrm{C}\right)$} & \multirow{2}{*}{$\begin{array}{c}\text { Wind speed } \\
\left(\mathrm{kg} \mathrm{day}^{-1}\right)\end{array}$} & \multirow{2}{*}{$\begin{array}{l}\text { RH } \\
(\%)\end{array}$} & \multicolumn{2}{|c|}{ Temperature $\left({ }^{\circ} \mathrm{C}\right)$} & \multirow{2}{*}{$\begin{array}{c}\text { Wind speed } \\
\left(\mathrm{kg} \mathrm{day}^{-1}\right)\end{array}$} & \multirow{2}{*}{$\mathrm{RH}(\%)$} \\
\hline & $\mathrm{T}_{\max }$ & $\mathrm{T}_{\min }$ & & & $T_{\max }$ & $\mathrm{T}_{\min }$ & & \\
\hline Dec & 17.7 & 11.6 & 155.5 & 37.8 & 16.9 & 11.4 & 156.0 & 30.7 \\
\hline Jan & 22.6 & 11.0 & 158.7 & 41.4 & 23.5 & 9.4 & 142.0 & 41.4 \\
\hline Feb & 23.3 & 11.9 & 167.9 & 45.5 & 22.0 & 11.0 & 152.1 & 45.1 \\
\hline Mar & 22.5 & 14.7 & 129.3 & 49.2 & 24.0 & 16.2 & 123.5 & 47.9 \\
\hline April & 29.1 & 17.0 & 89.1 & 52.5 & 27.4 & 17.2 & 88.2 & 55.4 \\
\hline May & 33.8 & 18.2 & 111.7 & 61.1 & 31.9 & 17.8 & 96.3 & 64.1 \\
\hline
\end{tabular}

All the agronomic practices were used as per the recommendation for canola crop. Before planting super phosphate $\left(15.5 \% \mathrm{P}_{2} \mathrm{O}_{5}\right)$ and potassium $\left(48 \% \mathrm{~K}_{2} \mathrm{O}\right)$ were applied to the soil. Nitrogen levels were provided in two equal doses, before first and second irrigation in form of ammonium nitrate $(33.5 \% \mathrm{~N})$ at the rate $108 \mathrm{~kg} / \mathrm{ha}$. The seeds were sown on 20th and 25th of October for both seasons.

\subsection{Data collection}

For data collections, 10 representative plants were randomly selected for each treatment in both the growing season.

\subsubsection{Growth characters}

Chlorophyll content was determined by Chlorophyll meter; model: SPAD-502, Minolta, Japan while Relative water content (RWC) was measured according to by Gao (2000) by estimating the turgid weight of $0.5 \mathrm{~g}$ fresh leaf samples by keeping them in water for $4 \mathrm{~h}$, followed by drying in hot air oven till constant weight using the formula given as the followeing: RWC $(\%)=[(\mathrm{W}-\mathrm{DW}) /(\mathrm{TW}-$ DW) $\times 100$. Where; $W$, fresh weight; TW , turgid weight; DW, dry weight.

\subsubsection{Yield attributes}

Plant height, number of branches, number of silica /plant, seeds/silique and seed yield/plant $(\mathrm{g})$ were recorded at the harvesting stage, and at harvesting, the rows in middle were harvested from the plot to estimate seed yield / ha

\subsubsection{Quality properties}

Oil content was also described according to the guide line of AOCS (1980) by using Soxhelt apparatus and petroleum ether (40$60^{\circ} \mathrm{C}$ ) as a solvent and Protein percentage of the canola seeds was determined by Kjeldahl method according (AOAC, 1980) while the crude protein was calculated by multiplying nitrogen percentage by converting factor of 6.25 .

\subsection{Statistical analysis}

Data obtained from the current investigation were subjected to an analysis of variance (ANOVA) procedures according to Gomez \& Gomez (1984) using the MSTAT-C statistical software package. Different means were compared using least significant difference (LSD) Test.

\section{Results and Discussion}

3.1 Effect of irrigation intervals on the growth, yield contributing traits and quality of canola

Statistical analysis for the data on growth, yield and quality traits showed highly significant differences among the three irrigation intervals (Table 2).The treatment with irrigation at every 25 days intervals was achieved the highest values for major tested traits. The chlorophyll and relative water content were significantly reduced with increasing the intervals of irrigation to 45 days (I3) for both the growing seasons (Table 2). Significant reduction was reported in the treatment $\left(\mathrm{I}_{3}\right)$ as compared to the $\left(\mathrm{I}_{1}\right)$ for both growth parameters. Chlorophyll content was positively influenced by irrigation intervals in the two years (Table 2).

The highest values of RWC was recorded form the control treatments in 2012 and 2013. Leaf relative water content is an essential physiological aspect which measured the drought stress tolerance in plants (Sánchez-Blanco et al., 2002). According to Reddy et al. (2004) water stress negatively influenced various physiological processes of plant which caused considerable reductions in final productivity. It was observed that, leaf chlorophyll content was reduced under water stress condition of plants (Sun et al., 2011).This reduction in chlorophyll contents under water deficit conditions is mainly due to the production of ROS that deteriorate the chloroplasts (Gill \& Tuteja, 2010). 
Table 2 Effect of irrigations intervals and antioxidants applications on the growth and yield traits of canola during 2012 and 2013 seasons.

\begin{tabular}{|c|c|c|c|c|c|c|c|c|}
\hline & \multicolumn{2}{|c|}{ Plant height (cm) } & \multicolumn{2}{|c|}{ Branch number/plant } & \multicolumn{2}{|c|}{ Relative water content (\%) } & \multicolumn{2}{|c|}{ SPAD value } \\
\hline & 2012 & 2013 & 2012 & 2013 & 2012 & 2013 & 2012 & 2013 \\
\hline \multicolumn{9}{|c|}{ Irrigation intervals } \\
\hline 25 days $\left(I_{1}\right)$ & $117^{\mathrm{b}}$ & $133^{\mathrm{a}}$ & $6.42^{\mathrm{a}}$ & $6.99^{\mathrm{a}}$ & $66.3^{\mathrm{a}}$ & $65.2^{\mathrm{a}}$ & $46.5^{\mathrm{a}}$ & $46.1^{\mathrm{a}}$ \\
\hline 35 days $\left(I_{2}\right)$ & $114^{\mathrm{b}}$ & $122^{\mathrm{b}}$ & $5.94^{\mathrm{a}}$ & $5.28^{\mathrm{b}}$ & $57.8^{\mathrm{b}}$ & $56.3^{\mathrm{b}}$ & $38.6^{\mathrm{b}}$ & $37.8^{\mathrm{b}}$ \\
\hline $45 \operatorname{days}\left(I_{3}\right)$ & $122^{\mathrm{a}}$ & $116^{\mathrm{c}}$ & $4.45^{\mathrm{b}}$ & $4.78^{\mathrm{b}}$ & $50.0^{\mathrm{c}}$ & $48.6^{\mathrm{c}}$ & $30.8^{\mathrm{c}}$ & $30.1^{\mathrm{c}}$ \\
\hline$P$ & $* *$ & $* * *$ & $* * *$ & $* * *$ & $* * *$ & $* * *$ & $* * *$ & $* * *$ \\
\hline \multicolumn{9}{|c|}{ Antioxidant application } \\
\hline Control & $115^{\mathrm{b}}$ & $116^{\mathrm{b}}$ & $4.98^{\mathrm{b}}$ & $5.11^{\mathrm{b}}$ & $52.4^{\mathrm{b}}$ & $51.3^{\mathrm{c}}$ & $37.4^{\mathrm{c}}$ & $36.7^{\mathrm{c}}$ \\
\hline Salicylic acid & $119^{\mathrm{ab}}$ & $128^{\mathrm{a}}$ & $5.92^{\mathrm{a}}$ & $5.88^{\mathrm{a}}$ & $60.1^{a}$ & $58.5^{\mathrm{b}}$ & $39.8^{\mathrm{a}}$ & $39.1^{\mathrm{a}}$ \\
\hline Ascorbic acid & $120^{\mathrm{a}}$ & $128^{\mathrm{a}}$ & $5.92^{\mathrm{a}}$ & $6.05^{\mathrm{a}}$ & $61.6^{\mathrm{a}}$ & $60.2^{\mathrm{a}}$ & $38.8^{\mathrm{b}}$ & $38.1^{\mathrm{b}}$ \\
\hline$P$ & $*$ & $* * *$ & **** & $* *$ & $* * *$ & $* * *$ & $* * *$ & $* * *$ \\
\hline
\end{tabular}

$* ; * * ; * *$ and N.S. indicate $P<0.05, P<0.01, P<0.001$ and not significant, respectively. Means of each factor designated by the same latter are not significantly different at $5 \%$ level using Least significant Difference (LSD) Test

Various growth and yield components like plant height, silica number per plant, number of branches per plant and seed yield/plant were also significantly affected by the increasing the intervals between irrigations and these parameters were reported higher in 25 day $\left(\mathrm{I}_{1}\right)$ while the lowest value in plant irrigated with compare 45 days intervals $\left(I_{3}\right)$ (Table 2,3). Evidently, irrigations intervals exhibited differences in seed yield traits (Table 2, 3) and it was observed 3092 and $3154 \mathrm{~kg} / \mathrm{ha}$ in 2012 and 2013, respectively when the irrigation interval was 25 days. On the other hand, the lowest seed yield/ha (2582 and $2618 \mathrm{~kg} / \mathrm{ha})$ was produced by the irrigation intervals was 45 days in successive years. Like seed yield, other yield traits of canola are significantly influenced by irrigation intervals. Similarly, Hassanzadeh et al. (2005) reported that water deficit conditions reduced the number of siliques per plant. Further, Rahnema \& Bakhshandeh (2006) also reported that number of pods per plant, seed yield and oil content of rape are effect by the water deficiency and reduced under water stress conditions. Malcolm \& Doug (2002) suggested the effect of the water deficit conditions on flower production and seed size and reported that water stress resulted in fewer flowers and seeds and produced seed are in small size. Lower number of branches, number of pods / plant and number of seed / plant was observed in different $B$. napus cultivars grown under water stress conditions and significant reduction in seed yield was observed when drought stress during flowering stage (Nasri et al., 2008). According to Zakerin et al. (2014) in rapeseed, growth and yield attributes were decreased under water deficit environment.

Irrigation treatments also significantly influenced the oil content and oil yield $(\mathrm{kg} / \mathrm{ha})$ as well as protein yield $(\mathrm{kg} / \mathrm{ha})$ of canola seed. Irrigation at every 25 days intervals produced the highest percentage of oil and oil yield, as well as protein yield followed by irrigation every 35 days which was ranked the second (Table 4). In contrast to oil content, it was observed that, protein content was non-significantly influenced under irrigations interval. Similar type of reduction in oil content was reported by the Zhang et al. (2014) under water deficient conditions which justly the phenomenon that reduction of oil contents in oil seed crops under water stress condition is a common incident. Further, Canola Council of Canada (2008) also suggested that optimum irrigation help in the increasing seed oil contents. Similar results were reported by Ali et al. (2003) in rape crop and Rashwan et al. (2016) in flax crop. Singh \& Sinha (2005) suggested that reduction in oil content could be due to the oxidation of some polyunsaturated fatty acids. Also, reduction in oil contents of crops under deficit irrigations is a familiar phenomenon (Ali et al., 2009). Moaveni et al. (2010) and Shirani Rad \& Zandi (2012) reported reduction in seed yield, which resulted in a reduction in oil yield under water stress conditions. Generally, the agronomic operations have an impact on the growth, yield and quality in different crops under different environments (Abd el-wahed et al., 2015; Barutcular et al., 2016a; Barutcular et al., 2016b; Gulluoglu et al., 2016 and Gulluoglu et al., 2017).

3.2 Effect of antioxidants applications on growth, yield contributing and quality of canola

Application of salicylic acid or ascorbic acid significantly influenced the growth, yield and quality traits of canola (Table 2, 3 \& 4). Findings of this study revealed that chlorophyll content and RWC improved with the application of antioxidants. Ebrahimian \& Bybordi (2012) suggested that application of ascorbic acid increased the rate of photosynthesis by increasing the chlorophyll content which in turn leads to an improve in assimilates rates (sugars). Raymond \& Houtte (2012) observed that foliar application of AA resulted to improve the relative water content (RWC). Like Ascorbic acid, salicylic acid also enhances the plants tolerance against various environmental stresses (Kolupaev et al., 2011). Further, He et al. (2005) also suggested that SA enhances the efficiency of photosynthetic apparatus which in turn improve the sap produced in leaves of plant and ultimately leads to maintain the RWC in leaves and a better growth of plant. According to Ahmadi et al. (2015) application of ASA under different soil moisture environments have various effects on RWC in plants. Also, SA could improve the tolerance in plants to different environmental stresses conditions (Kolupaev et al., 2011). 
Table 3 Effect of irrigations intervals and antioxidants applications on the seed yield and yield traits of canola during 2012 and 2013 seasons.

\begin{tabular}{|c|c|c|c|c|c|c|c|c|}
\hline & \multicolumn{2}{|c|}{ Silica number/plant } & \multicolumn{2}{|c|}{ Seeds number / silica } & \multicolumn{2}{|c|}{ Seed yield (g/plant) } & \multicolumn{2}{|c|}{ Seed yield $(\mathrm{kg} / \mathrm{ha})$} \\
\hline & 2012 & 2013 & 2012 & 2013 & 2012 & 2013 & 2012 & 2013 \\
\hline \multicolumn{9}{|c|}{ Irrigation intervals } \\
\hline 25 days $\left(I_{1}\right)$ & $150^{\mathrm{a}}$ & $134^{\mathrm{a}}$ & 19.3 & 20.4 & $17.0^{\mathrm{a}}$ & $16.8^{\mathrm{a}}$ & $3092^{\mathrm{a}}$ & $3154^{\mathrm{a}}$ \\
\hline 35 days $\left(I_{2}\right)$ & $139^{\mathrm{b}}$ & $115^{\mathrm{b}}$ & 20.6 & 19.7 & $13.8^{\mathrm{b}}$ & $13.3^{\mathrm{b}}$ & $2721^{b}$ & $2748^{\mathrm{b}}$ \\
\hline 45 days $\left(I_{3}\right)$ & $105^{\mathrm{c}}$ & $115^{\mathrm{b}}$ & 18.1 & 18.4 & $13.2^{\mathrm{b}}$ & $13.1^{\mathrm{b}}$ & $2582^{\mathrm{c}}$ & $2618^{c}$ \\
\hline $\boldsymbol{P}$ & $* * *$ & $* * *$ & N.S. & N.S. & $* * *$ & $* * *$ & $* * *$ & $* * *$ \\
\hline \multicolumn{9}{|c|}{ Antioxidant application } \\
\hline Control & $122^{\mathrm{b}}$ & $110^{\mathrm{b}}$ & $16.7^{\mathrm{b}}$ & $16.5^{\mathrm{b}}$ & $13.6^{\mathrm{b}}$ & $13.2^{\mathrm{b}}$ & $2465^{\mathrm{c}}$ & $2578^{\mathrm{b}}$ \\
\hline Salicylic acid & $137^{\mathrm{a}}$ & $126^{\mathrm{a}}$ & $20.4^{\mathrm{a}}$ & $20.7^{\mathrm{a}}$ & $15.1^{\mathrm{a}}$ & $14.9^{\mathrm{a}}$ & $2899^{\mathrm{b}}$ & $2964^{\mathrm{a}}$ \\
\hline Ascorbic acid & $135^{\mathrm{a}}$ & $126^{\mathrm{a}}$ & $20.9^{\mathrm{a}}$ & $21.4^{\mathrm{a}}$ & $15.2^{\mathrm{a}}$ & $15.0^{\mathrm{a}}$ & $3030^{\mathrm{a}}$ & $2979^{\mathrm{a}}$ \\
\hline$P$ & $* * *$ & $* * *$ & $* *$ & $* *$ & $* *$ & $* * *$ & $* * *$ & $* * *$ \\
\hline
\end{tabular}

$* *, * * *$ and N.S. indicate $P<0.05, P<0.01, P<0.001$ and not significant, respectively. Means of each factor designated by the same latter are not significantly different at $5 \%$ level using least significant Difference (LSD) Test.

Table 4 Effect of irrigations intervals and antioxidants applications on the quality traits of canola during 2012 and 2013 seasons.

\begin{tabular}{|c|c|c|c|c|c|c|c|c|}
\hline & \multicolumn{2}{|c|}{ Oil content (\%) } & \multicolumn{2}{|c|}{ Protein content (\%) } & \multicolumn{2}{|c|}{ Oil Yield (kg/ha) } & \multicolumn{2}{|c|}{ Protein yield (kg/ha) } \\
\hline & 2012 & 2013 & 2012 & 2013 & 2012 & 2013 & 2012 & 2013 \\
\hline \multicolumn{9}{|c|}{ Irrigation intervals } \\
\hline 25 days $\left(I_{1}\right)$ & $43.5^{\mathrm{a}}$ & $42.2^{\mathrm{a}}$ & 22.1 & 22.6 & $1344^{\mathrm{a}}$ & $1333^{\mathrm{a}}$ & $682^{\mathrm{a}}$ & $713^{\mathrm{a}}$ \\
\hline 35 days $\left(I_{2}\right)$ & $38.5^{\mathrm{b}}$ & $37.7^{\mathrm{b}}$ & 21.6 & 22.0 & $1046^{\mathrm{b}}$ & $1037^{\mathrm{b}}$ & $591^{\mathrm{b}}$ & $607^{\mathrm{b}}$ \\
\hline 45 days $\left(I_{3}\right)$ & $37.1^{\mathrm{c}}$ & $36.9^{\mathrm{b}}$ & 21.5 & 22.0 & $960^{c}$ & $968^{c}$ & $557^{\mathrm{c}}$ & $581^{\mathrm{b}}$ \\
\hline$P$ & $* * *$ & $* * *$ & N.S. & N.S. & $* * *$ & $* * *$ & $* * *$ & $* * *$ \\
\hline \multicolumn{9}{|c|}{ Antioxidant application } \\
\hline Control & 39.3 & 38.5 & $21.2^{\mathrm{b}}$ & $21.3^{\mathrm{b}}$ & $982^{c}$ & $1009^{\mathrm{b}}$ & $525^{\mathrm{b}}$ & $555^{\mathrm{b}}$ \\
\hline Salicylic acid & 39.7 & 39.1 & $22.1^{\mathrm{a}}$ & $22.4^{\mathrm{a}}$ & $1154^{\mathrm{b}}$ & $1159^{\mathrm{a}}$ & $640^{\mathrm{a}}$ & $663^{\mathrm{a}}$ \\
\hline Ascorbic acid & 40.1 & 39.2 & $21.9^{\mathrm{ab}}$ & $22.9^{\mathrm{a}}$ & $1215^{\mathrm{a}}$ & $1170^{\mathrm{a}}$ & $664^{\mathrm{a}}$ & $683^{\mathrm{a}}$ \\
\hline$P$ & N.S. & N.S. & $*$ & $* *$ & $* * *$ & $* * *$ & $* * *$ & $* * *$ \\
\hline
\end{tabular}

*; **; *** and N.S. indicate $P<0.05, P<0.01, P<0.001$ and not significant, respectively. Means of each factor designated by the same latter are not significantly different at $5 \%$ level using least significant Difference (LSD) Test

The integrated management practices have an influence the productivity in various crops under different environmental conditions (EL Sabagh et al., 2015b; EL Sabagh et al., 2016c; EL Sabagh et al., 2017; Gormus et al., 2016a; Gormus et al., 2016b and Gormus et al., 2017).

Exogenous application of salicylic acid or ascorbic acid significantly increased yield and yield related components. The highest seed yield was produced by the application of both antioxidants (3030 and $2979 \mathrm{~kg} / \mathrm{ha}$ respectively) in both growing seasons. Results of study revealed that application of ascorbic acid was found more effective than the salicylic acid in enhancing the yield under deficit irrigation conditions (Table 3). The control treatment (non-treated) produced the minimum seed yield (2456 and 2578 respectively) in both growing seasons. In this manner, findings of this study are in accordance with the findings of Ullah et al. (2012) those who have reported that application of salicylic acid could mitigate the adverse effects of drought on rape. Moreover, application of salicylic acid increased the concentration of cellular osmolytes which enhance the accumulation of soluble proteins and proline in order to improve RWC which resulted in improved photosynthetic pigments under water stress environments. Similarly, Sakhabutdinova et al. (2003) reported that spraying of salicylic acid on drought affected plants increased the level of relative water, chlorophyll, carotenoid and proline as compared to untreated plants. Generally, higher chlorophyll content might cause better productivity under stress (Rao et al., 2012).

Application of these antioxidants significantly influenced the protein percentage of canola seed (Table 4) while non-significant variation was reported in terms of the oil content (Table 4). It was observed that, the antioxidants applications achieved superior yield $(\mathrm{kg} / \mathrm{ha})$ which, resulted in significantly increase in protein and oil yield/ha (Table 4). Ahmadi et al. (2015) reported that spraying of $300 \mathrm{mg} \mathrm{L}^{-1}$ ascorbate peroxidase reducing the effect of drought stressed on rape crops. 


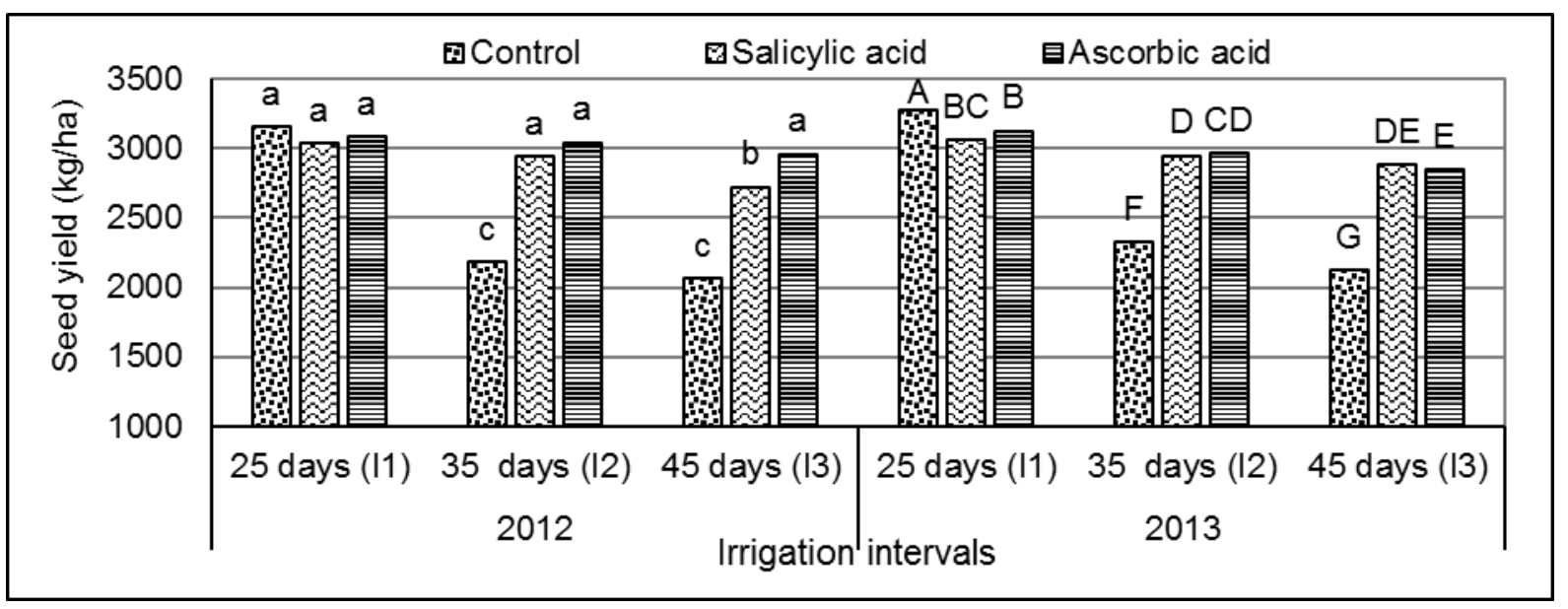

Figure 1 Seed yield /ha (kg) as affected by the interaction between irrigation intervals and antioxidants applications during 2012 and 2013 seasons

3.3 Interaction effect between phytohormones and irrigation intervals on different agronomical traits of canola

Result of this study indicated that interaction between antioxidant applications and irrigation intervals was highly significant for major traits of canola. The chlorophyll and RWC were influenced by the interaction of irrigation intervals and antioxidants, and applications of both antioxidants with irrigation at 25 days produced the highest positive values of RWC and chlorophyll content. Maximum silica number per plant was achieved by the applications of both antioxidants in combined with irrigation every 25 days, which lead to increase seed yield /ha (Fig.1). Results of study revealed that antioxidants applications are positively correlated with the yield components and, lead to an increase in seed yield/ha, which caused the improvement in oil and protein yield/ha. As well as, in present research, oil and protein yield were also improved by applications of both antioxidants in combined with irrigation every 25 days. The increase of oil and protein yield may be due to higher yield (kg/ha) of canola plant (Figure $2 \& 3$ ).

Considering the results of this study, it could be concluded that foliar applications of antioxidants under various irrigation intervals conditions have different impacts on canola productivity. Ascorbic acid is playing significant role in the enhancement of plants against various environmental stresses (Vwioko et al., 2008; Saruhan et al., 2012). Ascorbic acid, can decrease the harmful effect of oxidative stress and enhancing the plants growth under stress environment (Dolatabadian et al., 2009). SA in a appreciative rate enhanced the antioxidant ability of cell and generated new protein synthesis in the photosynthetic apparatus (Tirani et al., 2013). According to El-Tayeb (2005), who recorded that SA application decreased the stress-induced loss in chlorophyl content and photosynthetic rate under stress conditions.

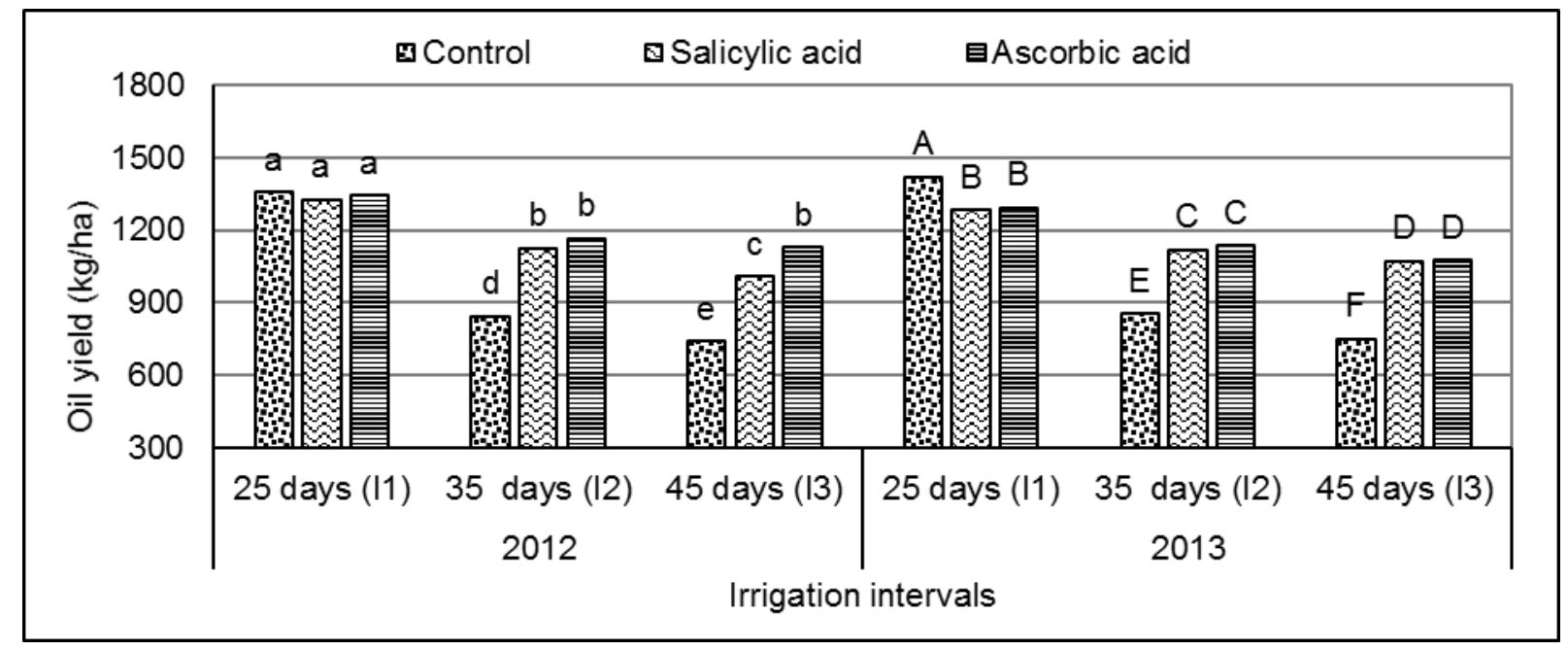

Figure 2 Oil yield (kg/ha) as affected by the interaction of irrigation intervals and antioxidants applications during 2012 and 2013 seasons 


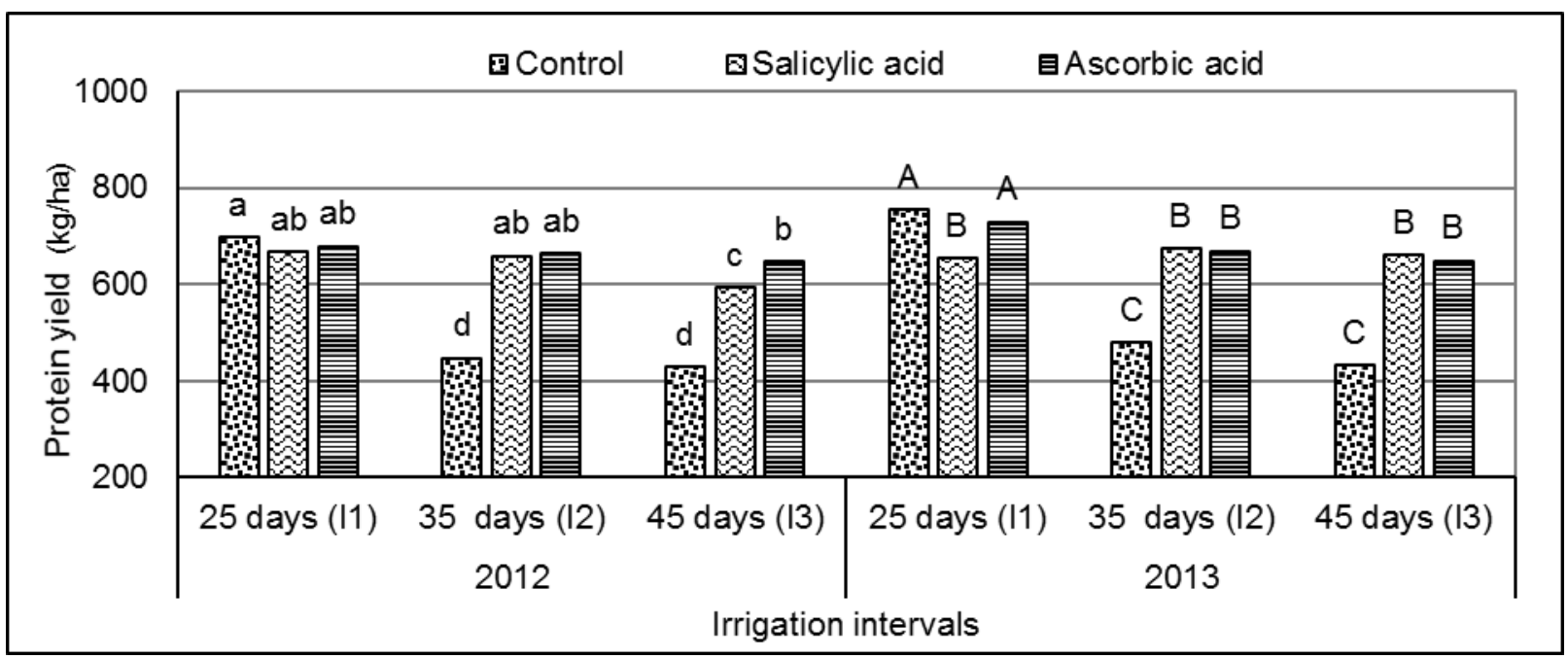

Figure 3 Protein yield(kg/ha) as affected by the interaction of irrigation intervals and antioxidants applications during 2012 and 2013 seasons

\section{Conclusion}

From the findings of this study it could be conclude that the irrigation intervals have a significant impact on canola growth, yield and quality traits. Application of antioxidants had significant impact on the growth, seed yield and quality traits of canola under water deficient conditions. The maximum seed yield/ha was achieved by the applications of both antioxidants combined with irrigation every 25 days. Accordingly, the farming under full irrigation (normal conditions) in North Nile Delta, may doesn't need to apply antioxidant. However, the antioxidants application requires further investigation in canola at different growth phases under various environments.

\section{Conflict of interest}

Authors would hereby like to declare that there is no conflict of interests that could possibly arise.

\section{References}

Abd el-wahed MH, EL Sabagh A, Zayed A, Sanussi A, Saneoka A, Barutçular C (2015) Improving yield and water productivity of maize grown under deficit-irrigated in dry area conditions. Azarian Journal of Agriculture 2, 123-132.

Ahmadi SAK, Ebadi A, Daneshian J, Jahanbakhsh S, Siadat SA, Tavakoli H (2015) Effects of irrigation deficit and application of some growth regulators on defense mechanisms of canola. Notulae Botanicae Hortica Agrobotanici ClujNapoca 43: 1-10. DOI: http://dx.doi.org/10.15835/nbha4319668.

Ali N, Javidfar F, Elmira JY, Mirza MY (2003) Relationship among yield components and selection criteria for yield improvement in winter rapeseed (Brassica napus L.). Pakistan Journal of Botany 35: 167-174.

Ali Q, Ashraf M, Anwar F (2009) Physico-chemical attributes of seed oil from drought stressed sunflower (Helianthus annuus L.) plants. Grasas y Aceites 60 : 475-481. DOI: 10.3989/gya.021009.

Amin AA, El-Sh M Rashad, Fatma, Gharib AE (2008) Changes in morphological, physiological and reproductive characters of wheat plants as affected by foliar spraying application with salicylic acid and ascobien. Australian Journal of Basic Applied Science 2: 252-261.

Anonymous (2013) Oilseeds and products annual. USDA Foreign Agricultural Service, Global Agricultural Information Network (GAIN Report). Available on http://gain.fas.usda.gov access on 29th April, 2015.

AOAC (1980) Association of official agriculture chemists "official methods of analysis" $13^{\text {th }}$ Ed., Washington, DC, USA. Barutcular C, EL Sabagh A, Konuskan O, Saneoka H (2016b) evaluation of maize hybrids to terminal drought stress tolerance by defining drought indices. Journal of Experimental Biology and Agricultural Sciences 4:610-616.DOI: http://dx.doi.org/10.18006/2016.

Barutçular C, Dizlek H, EL- Sabagh A, Sahin T, EL- Sabagh M, Islam MS (2016a) Nutritional quality of maize in response to drought stress during grain-filling stages in mediterranean climate condition. Journal of Experimental Biology and Agricultural Sciences 4: 644-652. DOI: 10.18006/2016.4 (Issue6).644.652. 
Black CA (Ed.) (1965) Method of Soil Analysis, Part 2, Chemical and Microbiological Properties, American Society of Agronomy, Inc, Publisher, Madison, Wisconsin USA

Bremner JM (1960) Determination of nitrogen in soil by the Kjeldahl method. Journal Agriculture Science 55: 11-37.

Canola Council of Canada (2008) Effects of moisture on canola growth. Winnipeg, Canada.

Dawood MG, Sadak MS (2014) Physiological role of glycinebetaine in alleviating the deleterious effects of drought stress on canola plants (Brassica napus L.). Middle East Journal of Agriculture Research 3: 943-954.

Dolatabadian A, Modarres Sanavy SAM, Sharifi M (2009) The effect of ascorbic acid on leaf feeding activity of antioxidant and proline accumulation in rapeseed (Brassica napus L.) in terms of salinity. Agriculture Sciences and Natural Resources $13: 611-621$.

Ebrahimian E, Bybordi A (2012) Influence of ascorbic acid foliar application on chlorophyll, flavonoids, anthocyanin and soluble sugar contents of sunflower under conditions of water deficit stress. Journal of Food Agriculture Environment 10:1026-1030.

EL Sabagh A, Sorour S, Morsi A, Islam MS, Ueda A, Barutcular C, Arioglu H, Saneoka H (2016c ) Role of Osmoprotectants and compost application in improving water stress tolerance in soybean (Glycine max L.). International Journal of Current Research 8 : 25949-25954

EL Sabagh A, Abd El-Rasool S, Islam MS, Barutcular C, Omar A (2016b) Improving growht of canola (Brassica napus L.) plants by seed inoculation and inorganic - organic nitrogen fertilization. Asian Journal of Science and Technology 7: 22832288.

EL Sabagh A, Barutcular C, Islam MS (2017) Relationships between stomatal conductance and yield under deficit irrigation in maize (Zea mays L.). Journal of Experimental Biology and Agricultural Sciences 5:15-21. DOI $10.18006 / 2017.5$ (1).014.021.

EL Sabagh A, Barutcular C, Saneoka H (2015b) Assessment of drought tolerance maize hybrids at grain growth stage in Mediterranean area. International Journal of Biological, Biomolecular, Agricultural, Food and Biotechnological Engineering 9: 962-965.

EL Sabagh A, Omar A, Saneoka H, Barutçular C (2015a) Evaluation agronomic traits of canola (Brassica napus L.) under organic, bio and chemical fertilizers. Dicle University Institute of Natural and Applied Science Journal 4: 59-67.
EL Sabagh A, Omar A, Saneoka H, Barutçular C (2016a) A Role of integrated use of nitrogen fertilizer sources in improving seed quality of canola (Brassica napus L.). Turkish Journal of Agriculture-Food Science and Technology 4:73-78.

El-Khallal SM, Hathout TA, Ahsour AEA, Kerrit AAA (2009) Brassinolide and salicylic acid induced antioxidant enzymes, hormonal balance and protein profile of maize plants grown under salt stress. Research journal of agriculture and biological sciences $5: 391-402$.

El-Tayeb MA (2005) Response of barley gains to the interactive effect of salinity and salicylic. - Plant Growth Regulation 45: 215- 225. DOI 10.1007/s10725-005-4928-1.

Gao F (2000) Experimental technology in plant physiology. World Books Publishing Company, China.

Ghobadi M, Bakhshandeh M, Fathi G, Gharineh MH, Alamisaeed K, Naderi A, Ghobadi V (2006) Short and long periods of water stress during different growth stages of canola (Brassica napus L.). Effect on yield, yield components, seed oil and protein contents. Journal of Agronomy 5: 336-341. DOI: $10.3923 /$ ja.2006.336.341

Gill SS, Tuteja N (2010) Reactive oxygen species and antioxidant machinery in abiotic stress tolerance in crop plants. Plant Physiology and Biochemistry 48: 909-930. doi: 10.1016/j.plaphy.2010.08.016.

Gomez KA, Gomez AA (1984) Statistical procedures for agricultural research. Wiley Inter Science, New York.

Gormus O, EL Sabagh A, Harun R, Islam MS (2017) Enhancement of productivity and fiber quality by defining ideal defoliation and harvesting timing in cotton. Romanian Agricultural Research 34 : DII 2067-5720 RAR 2017-39.

Gormus O, EL Sabagh A (2016b) Effect of nitrogen and sulfur on the quality of the cotton fiber under mediterranean conditions. Journal of Experimental Biology and Agricultural Sciences 4 : 662-669. DOI: 10.18006/2016.4(Issue6).662.669.

Gormus O, EL Sabagh A, Isalam MS (2016a) Optimizing yield and fiber quality of cotton under Mediterranean environment: managing nitrogen and potassium nutrition.Journal of Experimental Biology and Agricultural Sciences 4(S) : 572580. DOI: $10.18006 / 2016.4(5 S) .572 .580$.

Gulluoglu L, Bakal H, EL Sabagh A, Arioglu H (2017) Soybean managing for maximize production: plant population density effects on seed yield and some agronomical traits in main cropped soybean production. Journal of Experimental Biology and Agricultural Sciences $5: 31-37$. DOI: http://dx.doi.org/10.18006/2017.5(1).031.037. 
Gulluoglu L, Bakal H, Onat B, EL Sabagh A , Arioglu H ( 2016) Characterızation of peanut (Arachis hypogaea L.) seed oil and fatty acids composition under different growing season under mediterranean environment. Journal of Experimental Biology and Agricultural Sciences 4 (Suppl.) 565-571. DOI: http://dx.doi.org/10.18006/2016.4(5S).588.593.

Hamada A (2000) Amelioration of drought stress by ascorbic acid, thiamin or aspirin in wheat plants. Indian Journal of Plant Physiology 5:358-364.

Hassanzadeh M, Naderei M, Shiraneirad A (2005) Evaluation effects of drought stress on yield and yield components of autumn rapeseed cultivars in Isfahan. Journal of Agricultural Sciences 1: 51-62.

Hayat Q, Hayat S, Irfan M, Ahmad A (2010) Effect of exogenous salicylic acid under changing environment: A review. Environmental and Experimental Botany 68: 14-25. doi:10.1016/j.envexpbot.2009.08.005.

He Y, Liu Y, Cao W, Huai M, Xu B, Huang B (2005) Effects of salicylic acid on heat tolerance associated with antioxidant metabolism in Kentucky bluegrass. Crop Science 45: 988-995. doi:10.2135/cropsci2003.0678.

Johnston AM, Tanaka DL, Miller PR, Brandt SA, Nielsen DC, Lafond GP, Riveland NR (2002) Oilseed crops for semiarid cropping systems in the Northern Great Plains. Agronomy Journal 94: 231-240.

Kazemi M (2014) Effect of foliar application with salicylic acid and methyl jasmonate on growth, flowering, yield and fruit quality of tomato. Bulletin of Environment, Pharmacology and Life Sciences $3: 154-158$

Kolupaev Y, Yastreb T, Karpets YV, Miroshnichenko N (2011) Influence of salicylic and succinic acids on antioxidant enzymes activity, heat resistance and productivity of (Panicum miliaceum L). Journal of Stress Physiology \& Biochemistry 7:154-163.

Kowalczyk K, Zielony T (2008) Effect of aminoplant and asahi on yield and quality of lettuce grown on rockwool. Conference of biostimulators on modern agriculture held on 7-8 February 2008 at Warsaw, Poland.

Lizana C, Wentworth M, Martinez JP, Villegas D, Meneses R, Murchie EH, Pastenes C, Lercari B, Vernieri P, Horton P, Pinto M (2006) Differential adaptation of two varieties of common bean to abiotic stress. Journal of Experimental Botany 57: 685-697. DOI: https://doi.org/10.1093/jxb/erj062.
Malcolm JM, Doug WS (2002) Heat stress during flowering in summer Brassica. Crop Sciences 42: 797-803. doi:10.2135/cropsci2002.7970.

Moaveni P, Ebrahimi A, Farahani HA (2010) Studying of oil yield variations in winter rapeseed (Brassica napus L.) cultivars under drought stress conditions. Journal of Agricultural Biotechnology and Sustainable Development 2: $71-75$.

Nasri M, Khalatbari M, Zahedi H, Paknejad F, Tohidi Moghadam HR (2008) Evaluation of micro and macro elements in drought stress condition in cultivars of rapeseed (Brassica napus L.). American Journal of Agricultural and Biological Sciences 3: 579-583.

Noctor G, Foye CH (1998) Ascorbate and glutathione:keeping active oxygen under control. Annual. Rev. Plant Phys-iol. Plant Molecular Biology 49: 249-27. DOI: 10.1146/annurev.arplant.49.1.249.

Pignocchi C, Foyer CH (2003) Apoplastic ascorbate metabolism and its role in the regulation of cell signaling. Current Opinion in Plant Biology, 6, 379-389.

Rahnema AA, Bakhshandeh AM (2006) Determination of optimum irrigation level and compatible canola varieties in the Mediterranean environment. Asian Journal of Plant Sciences 5: 543-546. DOI: 10.3923/ajps.2006.543.546.

Rao SR, Qayyum A, Razzaq A, Ahmad M, Mahmood I, Sher A ( 2012) Role of foliar application of salicylic acid and 1tryptophan in drought tolerance of maize. Journal of Animal \& Plant Sciences 22: 768-772.

Rashwan E, Mousa A, EL-Sabagh A, Barutçular C (2016) Yield and quality traits of some flax cultivars as influenced by different irrigation intervals. Journal of Agricultural Science 8:226-240. DOI: http://dx.doi.org/10.5539/jas.v8n10p226

Rastegar MA (2004) Agronomy of Industrial Plants. Tehran, Iran.

Raymond F, Houtte V (2012) Effect of water stress, ascorbic acid and spraying time on some morphological and biochemical composition of Ocimum basilicum plant. International Journal of Agronomy and Environment 2:1-12.

Reddy AR, Chaitanya KV, Vivekanandan M (2004) Drought induced responses of photosynthesis and antioxidant metabolism in higher plants. Journal of Plant Physiology 161: 1189-1202. 
Reyes SU (2007) Canola oil available on http://www.ats.agr.gc.ca/asean/4359_access on $29^{\text {th }}$ April, 2016.

Rosales MA, Ruiz JM, Hernandez J, Soriano T, Castilla N. and Romero L (2006) Antioxidant content and ascorbate metabolism in cherry tomato exocarp in relation to temperature and solar radiation. Journal of the Science of Food and Agriculture, 86: 1545- 1551. DOI: 10.1002/jsfa.2546

Sakhabutdinova AR, Fatkhutdinova DR, Bezrukova MV, Shakirova FM (2003) Salicylic acid prevents damaging action of stress factors on wheat plants. Bulgarian Journal of Plant Physiology (Special Issue): 314-319.

Salarizdah M, Baghizadeh A, Abasi F, Mozaferi H, Salarizdah $S$ (2012) Response of Brassica napus L. grains to the interactive effect of salinity and salicylic acid. Journal of Stress Physiology \& Biochemistry 8 : 159-166.

Sánchez-Blanco MJ, Rodríguez P, Morales MA, Ortuño MF, Torrecillas A (2002) Comparative growth and water relation of Cistus albidus and Cistus monspeliensis plants during water deficit conditions and recovery. Plant Science, 162: 107-113. DOI: 10.1016/S0168-9452(01)00540-4.

Saruhan N, Saglam A, Kadioglu A (2012) Salicylic acid pretreatment induces drought tolerance and delays leaf rolling by inducing antioxidant systems in maize genotypes. Acta Physiologiae Plantarum, 34:97- 106. DOI: 10.1007/s11738011-0808-7.

Shakirova FM, Sakhabutdinova AR, Bezrukova MV, Fathkutdinova RA, Fatkhutdinova DR (2003) Changes in the hormonal status of wheat seedlings induced by salicylic acid and salinity. Plant Science 164: 317-322. https://doi.org/10.1016/S0168-9452 (02)00415-6.

Shalata A, Neumann PM (2001) Exogenous ascorbic acid (vitamin C) increases resistance to salt stress and reduces lipid peroxidation. Journal of Experimental Botany 52 : 2207-2211. DOI: https://doi.org/10.1093/jexbot/52.364.2207.
Shirani Rad AH, Zandi P (2012) The effect of drought stress on qualitative and quantitative traits of spring rapeseed (Brassica napus L.) cultivars. Žemdirbyst; Agriculture, 99, 4754.

Singh S, Sinha S (2005) Accumulation of metals and its effects in (Brassica juncea L.) Czern. (cv. Rohini) grown on various amendments of tannery waste. Ecotoxicology and Environmental Safety, Orlando 62:118- 127.

Sun C, Cao H, Shao H, Lei X, Xiao Y (2011) Growth and physiological responses to water and nutrient stress in oil palm. African Journal of Biotechnology 10: 10465-10471. http://dx.doi.org/10.5897/AJB11.463.

Tirani MM, Nasibi F, Kalantari KM (2013) Interaction of salicylic acid and ethylene and their effects on some physiological and biochemical parameters in canola plants (Brassica napus L.). Photosynthetica 51:411-418. DOI: 10.1007/s11099-013-0041-2.

Ullah F, Bano A, Nosheen A (2012) Effects of plant growth regulators on growth and oil quality of canola (Brassica napus L.) under drought stress. Journal of Botany 44: 1873-1880.

Vwioko ED, Osawaru ME, Eruogun OL (2008) Evaluation of Okra (Abelmoschus esculentus L. Moench.) exposed to paint waste contaminated soil for growth, ascorbic acid and metal concentration. African Journal of General Agriculture 4: 39-48.

Zakerin HR, Shirani Rad AH, Seifzadeh S, Valadabadi SA, Mostashari Mohasses M (2014) Evaluation the effect of Zn, Fe foliar application and variety on quality and physiological characteristics of canola (Brassica napus L.) under different ranges water deficit stress. Advances in Environmental Biology 8: 255-260.

Zhang X, Lu G, Long W, Zou X, Li F, Nishio T (2014) Recent progress in drought and salt tolerance studies in Brassica crops. Breeding Science 64: 60-73. doi: 10.1270/jsbbs.64.60. 